\title{
Connessioni e narrazioni. Racconto di un monastero
}

\author{
Alice Palmieri
}

Abstract

L'interpretazione del termine 'connettere' rivela significati che presentano caratteristiche differenti: in architettura per esempio la connessione può essere fisica, data dall'unione di più spazi; può essere intesa come strumento di pianificazione nella lettura urbana dei luoghi; può essere relazionale, interpretando la connessione come una comunicazione. Tutti gli aspetti messi in evidenza appartengono al racconto del Monastero di Santa Maria in Gerusalemme, nel centro antico di Napoli, in cui il tema della connessione si offre come chiave di lettura utile alla comprensione delle dinamiche della vita monastica, delle trasformazioni architettoniche dell'edificio e alle variazioni urbane nell'immediato intorno. Il contributo propone una ricerca in itinere, nata nell'ambito del protocollo d'intesa tra il Dipartimento di Architettura e Disegno Industriale dell'Università della Campania 'Luigi Vanvitelli' e il Monastero di Santa Maria in Gerusalemme, finalizzata alla ricostruzione storica della struttura monastica e della vita claustrale, al rilievo e al recupero del Chiostro, al progetto di valorizzazione e narrazione. La lettura presentata si basa su ricerche d'archivio, sopralluoghi e rilievi finora effettuati, che progressivamente restituiscono un quadro sempre più completo della struttura architettonica. Inoltre, data la natura dell'edificio, sono significativi gli aspetti percettivi che lasciano spazio ad ampie riflessioni sul tema della multi-sensorialità e sulla ricostruzione delle immagini e delle visuali perdute.

Parole chiave

architettura monastica, chiostro, percezione, traccia, immagine.

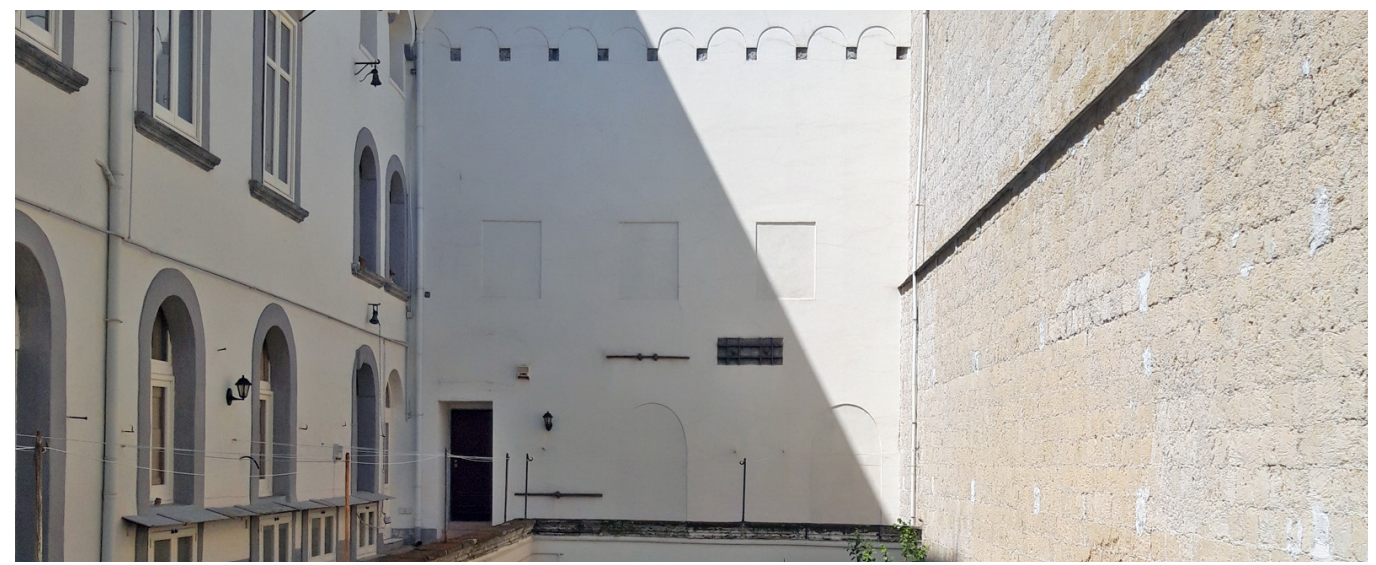




\section{Introduzione}

Interpretare il tema della connessione implica la considerazione delle molteplici declinazioni del verbo 'connettere': mettere insieme, unire, collegare, porre in relazione. Si tratta di azioni che possono assumere significato differente nella forma e nella 'messa in opera' della connessione. La stessa semantica del termine manifesta le possibilità interpretative che variano rispetto alla contestualizzazione, che può essere quella dell'architettura e intendere una connessione fisica, resa come unione di più ambienti al fine di creare una nuova conformazione spaziale, oppure una connessione relazionale, che rivela gli aspetti comunicativi e di dialogo, che possono corrispondere o meno ad una continuità tangibile. Connettere può voler dire richiamare alla memoria, ricongiungere presente e passato, rintrodurre nella vita quotidiana le tracce di una storia antica, magari lontana nel tempo, ma impressa nei luoghi. In questo senso il ricordo diventa il punto di avvio per la rappresentazione intesa come restituzione di un'immagine non più presente ma percepibile. Tutti gli aspetti messi in evidenza, appartengono al racconto del Monastero di Santa Maria in Gerusalemme, nel centro antico di Napoli: una struttura particolare per storia e conformazione, oggetto del Protocollo d'Intesa tra il Dipartimento di Architettura e Disegno Industriale dell'Università della Campania 'Luigi Vanvitelli' e il Monastero in cui il tema della connessione si propone come chiave di lettura utile alla comprensione delle dinamiche della vita monastica, delle trasformazioni architettoniche dell'edificio e parallelamente alle variazioni urbane dell'immediato intorno. Le modalità per mettere in connessione le due porzioni di chiostro adesso esistenti consentono di immaginare diversi approcci e allestimenti per ricomporre la continuità spaziale. II racconto dei cinque secoli di storia di questa comunità religiosa e le visioni per il futuro si articolano attraverso l'interpretazione della connessione come relazione tra interno ed esterno, reintegrazione dell'antico chiostro, connessione con la città, visualità e accessibilità.

Fig. I. Inquadramento territoriale dalla carta todi Noja (1775) da cui si di Noja (1775) da cui si del chiostro originario.

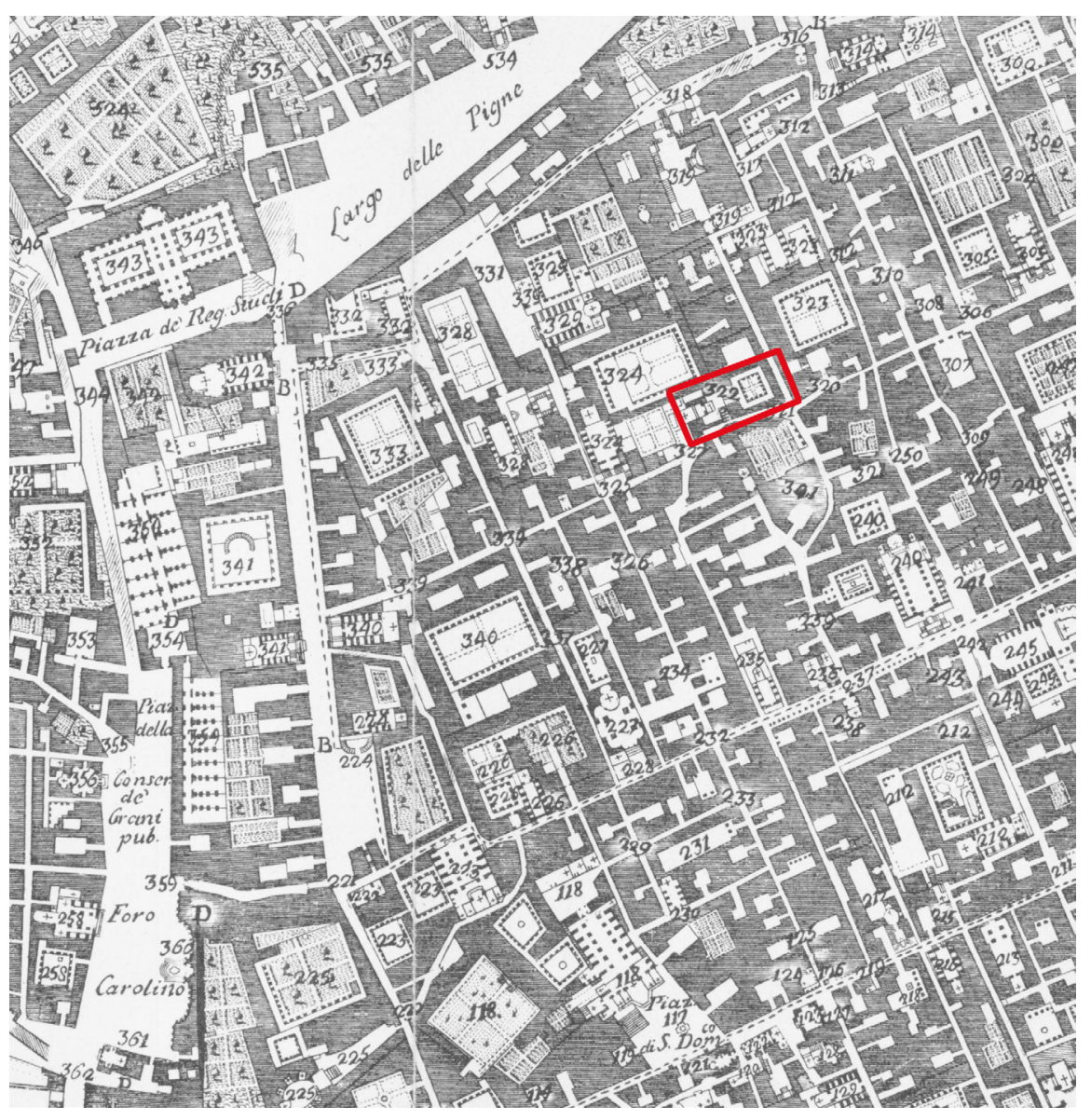




\section{Storia del Monastero delle Trentatré}

Il complesso monastico di Santa Maria in Gerusalemme, detto delle Trentatré (dal numero di monache che poteva accogliere) è fondato nel XVI secolo dalla nobildonna catalana Maria Lorenza Longo, giunta a Napoli nel I 506 al seguito di Ferdinando il Cattolico. È situato nella città greco-romana, sull'insula di fronte all'Odeon, poco distante dall'antico teatro Neapolis, all'interno delle mura antiche. La venerabile Maria Lorenza Longo, dopo la fondazione dell'Ospedale Incurabili ( 15 |9) riceve il 19 febbraio I 535 da Papa Paolo III la bolla Debitum Pastoralis officii con la quale viene autorizzata ad accogliere nei locali dell'ospedale la nascente comunità cappuccina. Ben presto, a causa dell'accresciuto numero di consacrate, è necessario il trasferimento che si rivela difficoltoso e solo nel I585, le monache entrano nell'attuale struttura. II monastero rispettava i dettami dell'architettura tipica dei conventi cappuccini e si affacciava su due chiostri, uno porticato e uno più semplice che fungeva da orto. Al piano terra il complesso si sviluppava intorno ai chiostri, dove erano collocate le officine necessarie per il lavoro delle sorelle (cucina, dispense, lavanderi etc.) e gli ambienti consueti per consentire la vita relazionale e affettiva delle monache, pertanto il chiostro era il vero centro regolatore della vita comune. II piano superiore era riservato al dormitorio con un'intera ala destinata all'infermeria, alla quale si accedeva da un parlatorio, con una cappella che serviva alla confessione e alla visita dei medici. II cenobio è costruito con materiale povero, tufo e piperno, senza sfarzo e con una buona esposizione al sole, spazi aperti e chiusi andavano alternandosi facendo entrare nell'insula monastica la luce necessaria alla vita claustrale. L'ingresso al monastero avviene da via Pisanelli, attraverso un'ampia scalinata al termine della quale si accede alla chiesa e sulla destra si trovano la ruota (ancora oggi funzionante) e l'accesso allo spazio proprio della clausura.

Con le leggi di soppressione post-unitarie (|86|-|866) brutali trasformazioni alterano il complesso monastico, abbattendo e trasformando aree considerevoli per la realizzazione di locali ad uso dell'Ospedale Incurabili, per arrivare nel Novecento alla demolizione di oltre metà del chiostro, del refettorio e del piano superiore con l'intero dormitorio. In conco-

Fig. 2. Porzione di chiostro ancora esistente, interrotta dalla realizzazione del muro tufaceo: un unico fronte rimane integro mentre i due bracci
laterali sono interrotti.

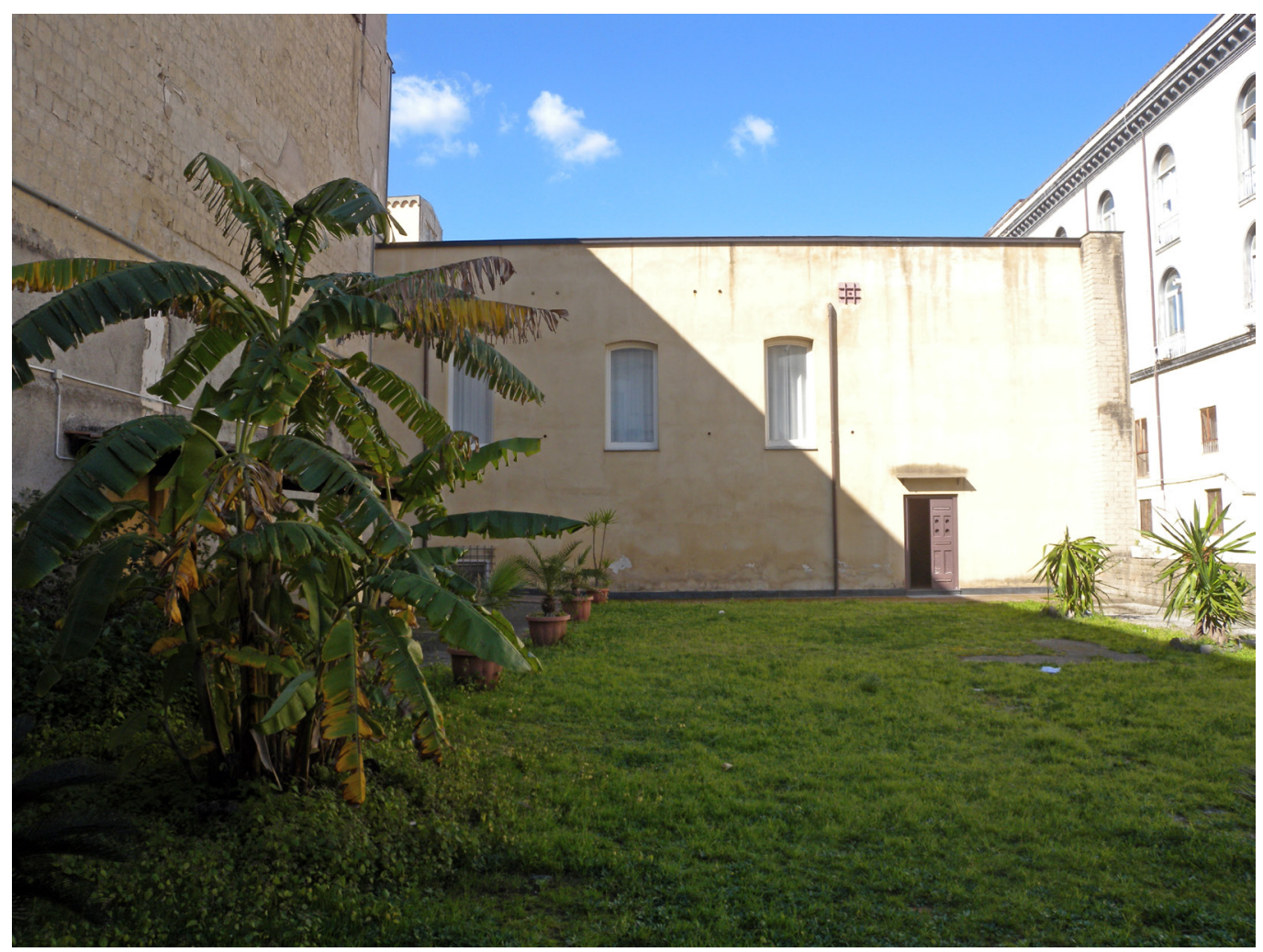


Fig. 3. Planimetria di inquadramento del Monastero tra via Pisanelli e vi Armanni. La forma circolare antistante la strada è l'insula dell'Odeon, mentre nell'angolo opposto è

stato rinvenuto l'antico

Teatro Neapolis.

Fig. 4. Pianta dello stato di fatto: dal disegno si evince la brutalità dell'intervento che demolendo il chiostro, lascia la struttura interrott e priva di continuità.
Fig. 5. Sezione longitudinale A-A: il muro di tufo, alto circa 15 metri incombe sull'area riservata alla della strada che definisce il piano di calpestio del chiostro è a circa 4 metri chiostro e a circa 4 metri stradale.
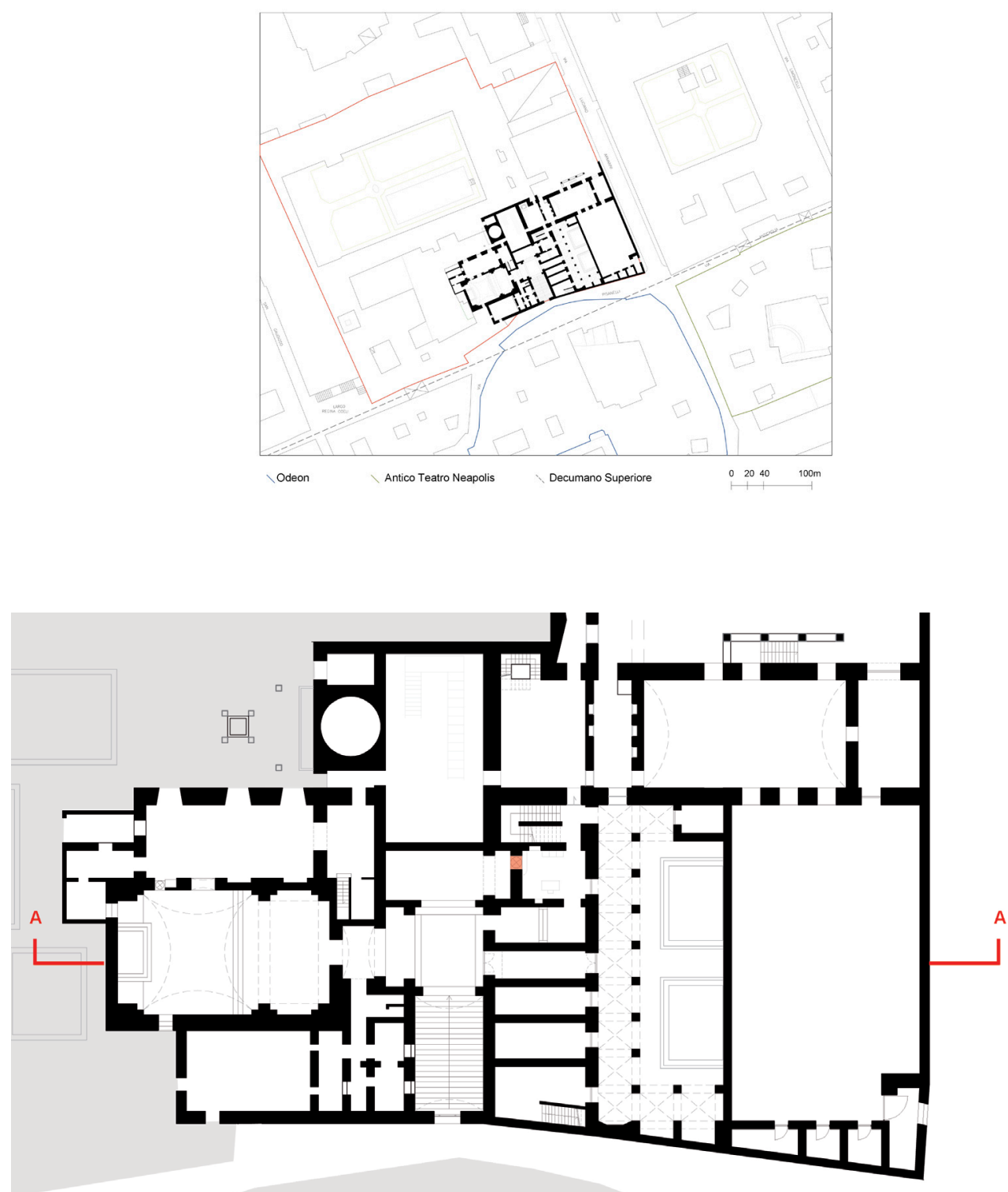

0

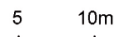

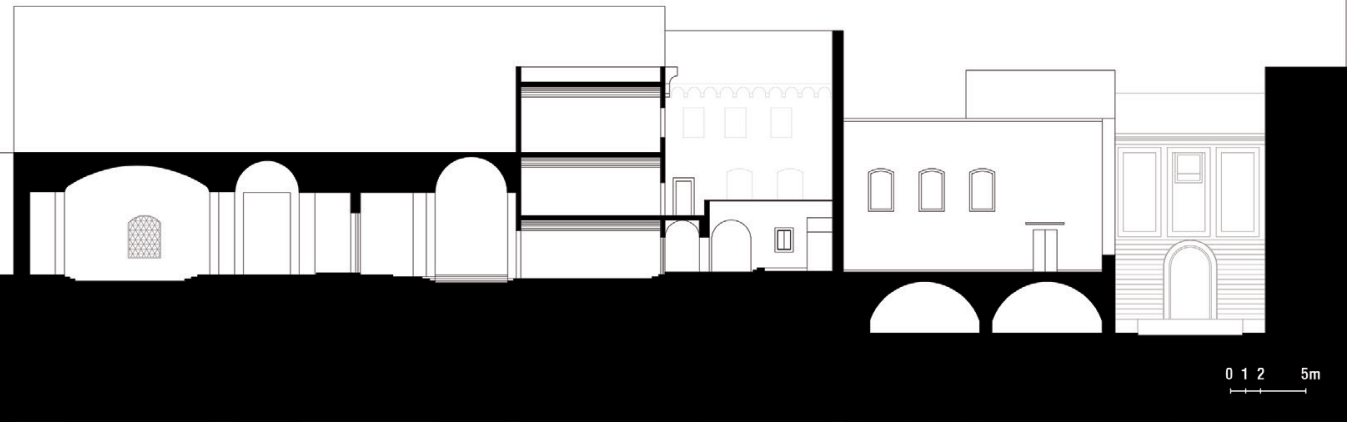




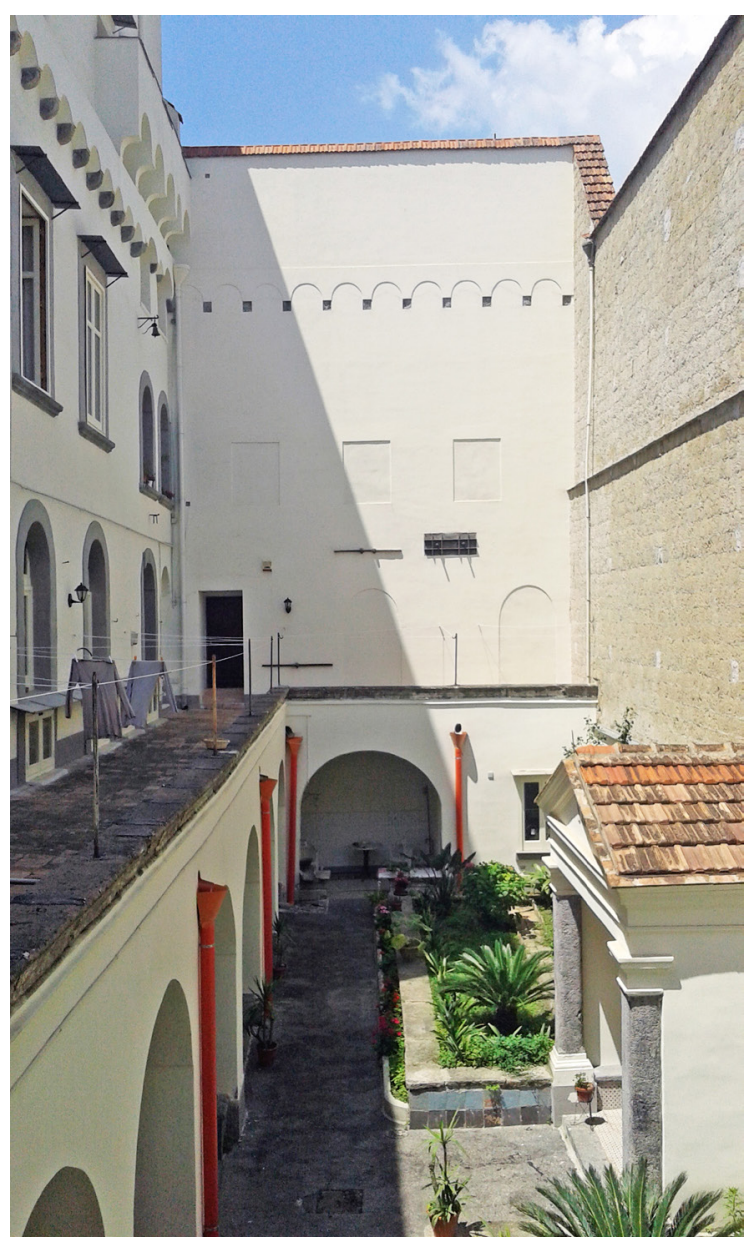

mitanza di questi eventi, vico degli Incurabili è allargato divenendo l'attuale via Armanni e in quel che era il refettorio delle monache, viene allestito un dispensario anti-tubercolare. In seguito l'area, ridotta ad un cumulo di ruderi, è definitivamente abbandonata dopo il terremoto del 1980. Solo nel 2003 lo spazio dell'ex-chiostro è ri-dato in comodato d'uso al Monastero, che ne aveva auspicato la restituzione e d'intesa con la Sovrintendenza e la Regione Campania, è attuato un progetto di ricostruzione filologica degli ambienti. Rinunciando alla clausura di questi luoghi, la sororità ha acconsentito alla realizzazione di una sala polifunzionale nell'antico refettorio inaugurato nel 2009, oggi aperto al pubblico.

\section{Connessione interno/esterno}

La caratteristica prevalente nella percezione di un monastero di clausura è l'inaccessibilità. Da sempre nell'immaginario collettivo rappresenta quel luogo in cui non si può entrare e soprattutto, da cui non si può uscire. La scelta, complicata e delicata, dalla vita di clausura è associata alla regola che vieta ai laici l'accesso alle parti interne dei conventi e all'obbligo che alcuni religiosi s'impongono nella professione dei voti, di non uscire dal monastero. Per questo motivo il termine 'clausura' è inteso anche come 'chiusura', implicando la negazione di qualsiasi connessione con il mondo e la vita esterna.

Avvicinandosi alla realtà delle Clarisse Cappuccine che abitano il Monastero di Santa Maria in Gerusalemme, emerge invece un racconto diverso da quello che possiamo immaginare. Un racconto di cittadini che nel pieno rispetto della regola, entrano in profonda connessione con le monache e la loro casa, attraverso la ruota. La definizione di 'ruota' corrisponde 
Fig. 7. II Monastero visto da via Armanni: le alte mura irregolari racchiudono lo spazio della clausura, fatta eccezione della superficie occupata dall'ex chiostro, parzialmente visibile dalla strada.

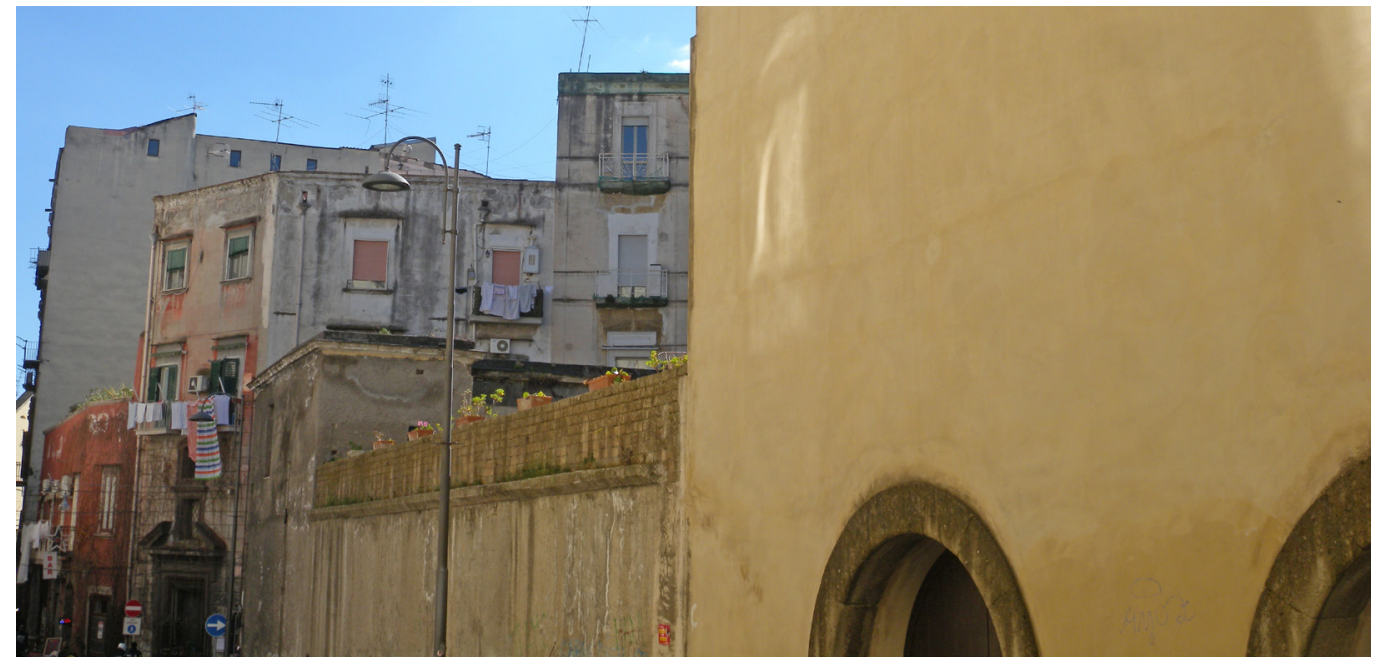

all'elemento architettonico, solitamente ligneo, costituito da un meccanismo girevole di forma cilindrica e diviso in due parti chiuse: una verso l'interno e un'altra verso l'esterno che, combaciando con una apertura su un muro, permette uno scambio con le monache senza alcun contatto visivo. Nel monastero delle Trentatré, la ruota non ha mai accolto infanti, non si trattava quindi di una 'rota degli esposti', ma serviva per donare le 'provvidenze' di cui si sostentavano le religiose e, come accade tutt'oggi, è il luogo di ascolto dove le clarisse accolgono la gente del luogo che affida loro preghiere, intenzioni e confidenze. L'elemento della ruota è quello che consente la relazione con l'esterno, è il punto in cui passano storie, racconti, odori, suoni, voci, un piccolo varco, che con la rotazione porta le cose da un lato all'altro, da fuori a dentro, dal mondo laico alla sacralità e riservatezza del monastero. Un'esperienza multisensoriale in cui è negata proprio la vista, oggi il senso dominante. Infatti,

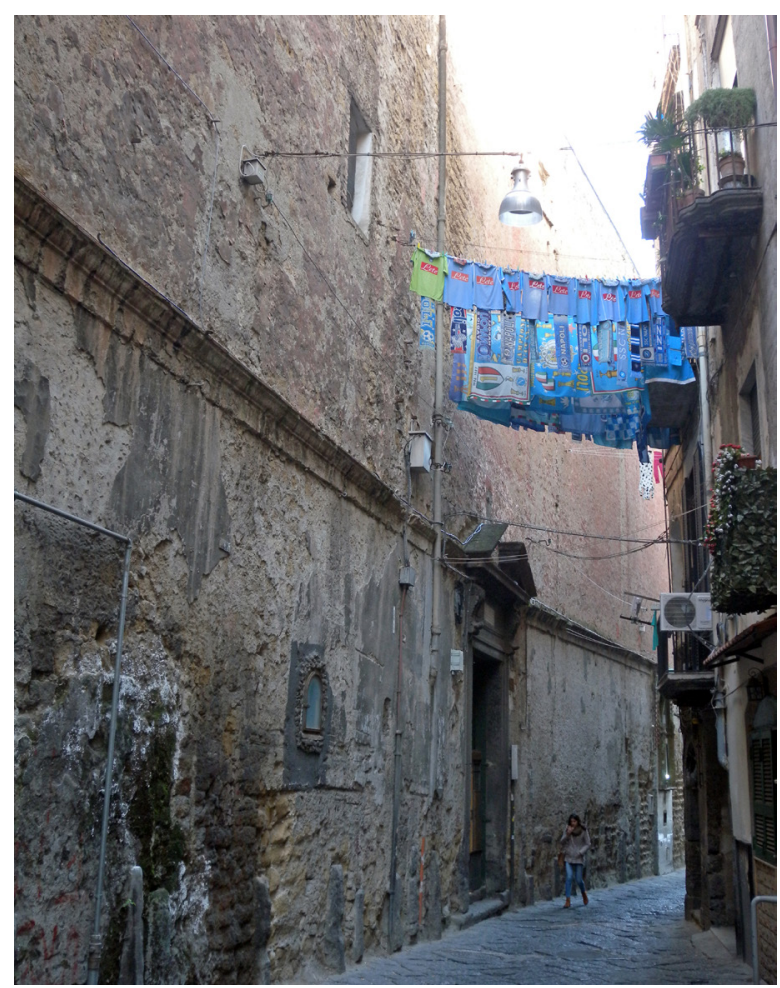


quando si parla di connessione, si dà sempre per scontato che la congiunzione di più luoghi implichi anche una continuità visiva, mentre la ruota nega questa condizione e si rivela strumento di una circostanza inedita, che interpella tutti gli altri sensi - in primis l'udito - rendendo i partecipanti al rapporto dentro/fuori componenti attivi e operativi della relazione. Un filtro pesante come la ruota potrebbe sembrare un ostacolo alla comunicazione, un limite (forse) insormontabile, invece in qualche modo la connessione si amplifica, si spoglia del superfluo e ridotta all'essenziale supera l'ostacolo.

Nel testo Comunicazione visiva, Ave Appiano descrive le manifestazioni sensoriali come "quelle ricche elaborazioni compiute dalla mente, in modo da attivare una comunicazione tra la realtà e la mente; le informazioni pervenute al cervello tramite i sensi si configurano secondo le modalità dettate dal pensiero diventando immagini. [...] L'immagine non è quindi solamente rappresentazione, figura o effetto di realtà date, ma l'esito di un'attività mentale e quindi deve essere considerata come il risultato di quel processo comunicativo che si attua tra l'individuo e la realtà" [Appiano 1993, p.4]. Questa considerazione che profondamente analizza la comunicazione come connessione tra persona e ambiente circostante, porta nel caso della ruota ad una conclusione molto significativa per cui, pur non avendo nessun contatto visivo con il mondo oltre l'oggetto, il visitatore riesce a desumerne un'immagine, basata su una percezione alternativa, che servendosi dell'udito, dell'olfatto e della dimensione prossemica, entra in relazione con una realtà invisibile.

Fig. 9. Lo spazio del chiostro demolito si presenta ora come un per la comunità religiosa. Sul fondo il prospetto del refettoriospetto ricostruito nel 2009.

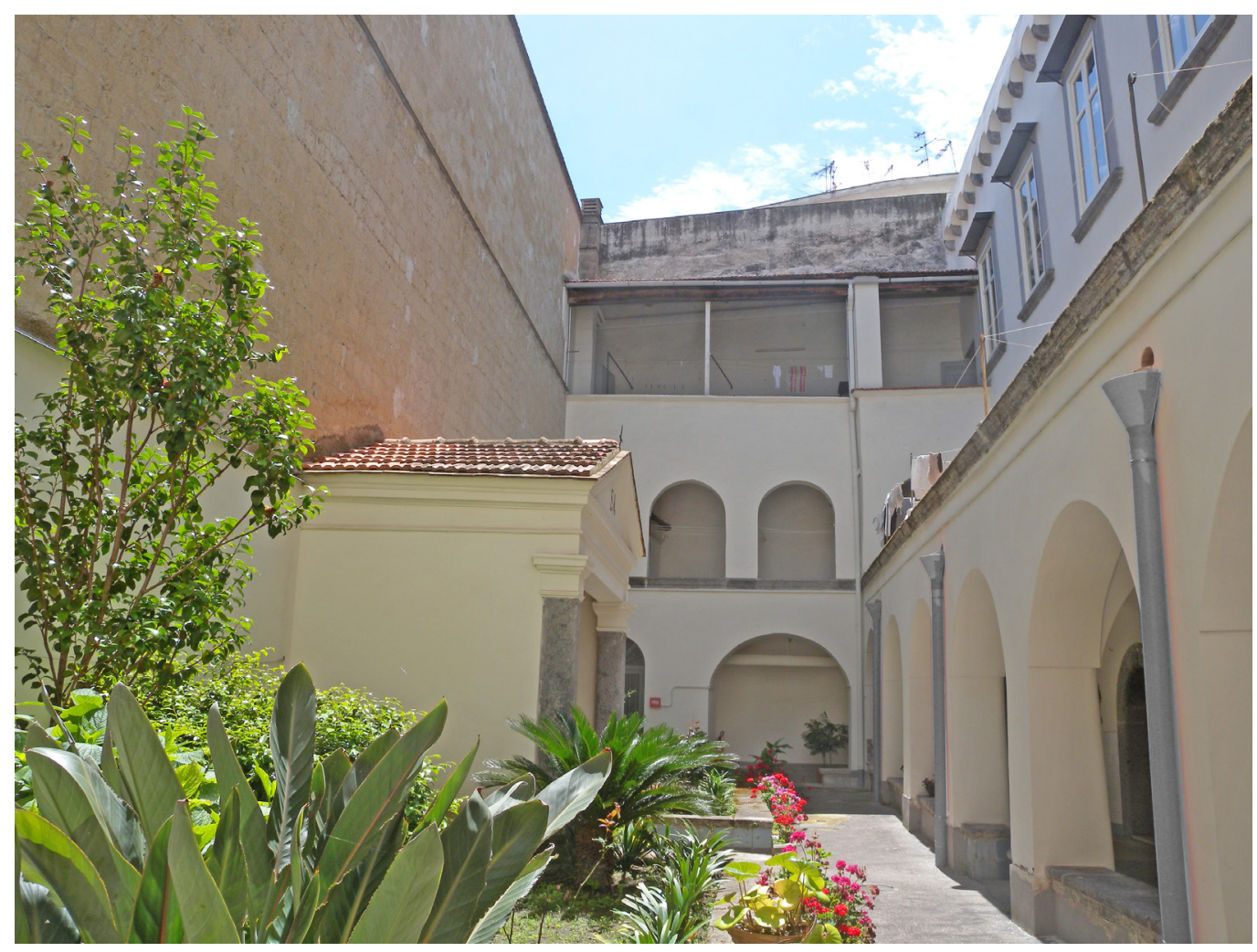

\section{Connessione con il passato}

Quella che potremmo definire una 'lacuna' nell'immagine del mondo interno del monastero può essere quindi superata da un'esperienza percettiva che affida ai visitatori il compito di costruire autonomamente un'idea basandosi sulla conoscenza multisensoriale e sulla capacità di concepire e immaginare la dimensione claustrale. II Monastero di Santa Maria in Gerusalemme, come anticipato nella descrizione della storia del complesso, ha un'ulteriore 
lacuna che è oggi oggetto di studio e ricerca. La questione dell'abbattimento del chiostro infatti, rimane ancora irrisolta, nonostante siano stati stanziati dei fondi per l'abbattimento del muro che divide le due parti. Tutto lo spazio che in origine era occupato dal chiostro è oggi frazionato in una piccola fascia in cui persiste un fronte intero dell'antico portico, e una superficie più ampia, dal lato di via Luciano Armanni che non è utilizzabile dalle monache perché non rispetta le condizioni di riservatezza previste dalla regola. Per quanto piccola, la porzione di chiostro ancora esistente costituisce una traccia preziosa per la comprensione dell'articolazione architettonica modificata nel corso del Novecento. Innanzitutto il portico integro lascia desumere la probabile configurazione degli altri lati, avvalorata da una planimetria redatta nel I 864, in seguito al decreto di soppressione delle case degli ordini religiosi. In questa documentazione d'archivio è riportata la pianta del piano terra a cui sono allegate le descrizioni della distribuzione degli ambienti ai livelli superiori e quindi delle celle che seguivano il perimetro del chiostro al secondo piano. Oltre a questo, in tempi recenti, su una facciata cieca prospiciente il chiostro esistente, sono state riportate alla luce le tracce delle aperture antiche e della cornice terminale del prospetto. L'immagine restituita appare come un disegno in scala reale, una rappresentazione che allude ai vuoti ormai non più esistenti e che si propone come narrazione perpetua dello stato dei luoghi. La riqualificazione della facciata ha restituito consistenza allo spazio che non è più limitato da un muro cieco, ma è cinto dalla rappresentazione simbolica del luogo che è stato, segno di memoria e di narrazione di una realtà perduta che ambisce ancora a farsi raccontare.

La presenza/assenza del chiostro e delle facciate originarie è il tema centrale nell'architettura del monastero poiché è fortemente percepibile il desiderio di vivere l'esperienza completa (e complessa) del luogo in cui il disegno, nel senso ampio di rappresentazione e 'assegnazione di senso', può essere uno strumento prezioso di intervento.

"In assenza dell'opera, una sua esperienza può aversi sia - ed è questo il caso più frequente - nelle sue rappresentazioni, intese come configurazioni e tecniche (disegno, pittura, fotografia, cinema, descrizione) atte a rendere in qualche modo visivamente presente ciò che non lo è materialmente, sia nella rimemorazione di un'esperienza trascorsa, sia infine tramite la mediazione dell'attività immaginativa che, nel caso dell'architetto, prende la forma del progetto" [Ugo |99|, p. 58].

L'esperienza cheVittorio Ugo definisce 'mediata' è resa quindi possibile dalla rappresentazione, dalla memoria e dal progetto-immaginazione. Rientra sicuramente in questo genere di approccio l'intervento di riqualificazione della facciata, mentre sono ancora in via di elaborazione le possibili attuazioni per raccontare la memoria del chiostro integro, che sarebbe improbabile ricostruire, ma che servendosi di nuove tecnologie e di strategie di storytelling, può ancora essere oggetto di narrazione.

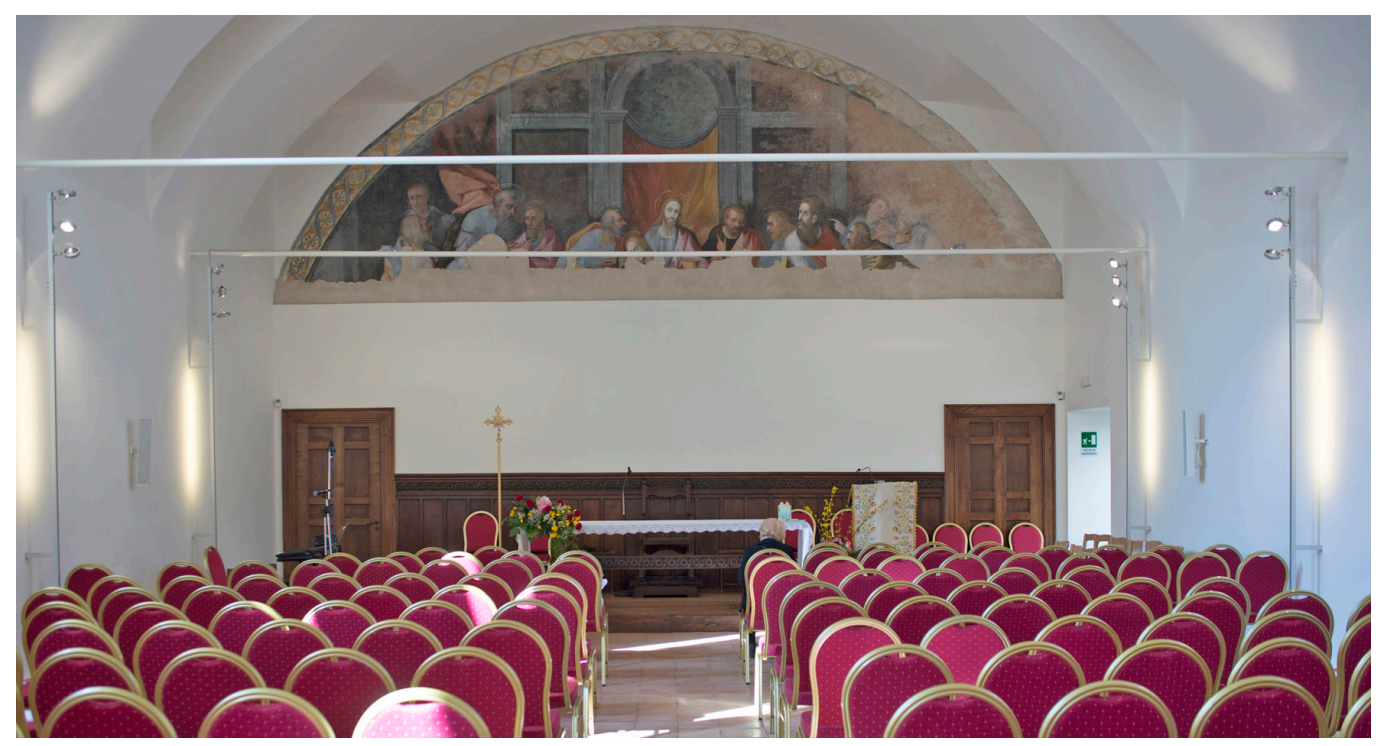




\section{Relazione con la città}

Con gli interventi di ripristino realizzati negli ultimi vent'anni, la comunità delle Clarisse Cappuccine ha accettato l'apertura al pubblico di alcune aree del monastero. In particolare il refettorio, completamente ricostruito, è oggi utilizzato per concerti, conferenze, incontri con le monache e vendite di beneficenza. Questo spazio affaccia sull'area dell'ex chiostro, delimitata dall'alto muro tufaceo e anch'essa accessibile, così come le cantine da cui si entra direttamente dalla strada e che potrebbe diventare in un prossimo futuro un museo di riggiole e ceramiche. La frequentazione del monastero da parte degli abitanti ne agevola la percezione e ne favorisce la conoscenza e con essa tutte le questioni legate alla demolizione del chiostro verso cui molti mostrano grande sensibilità.

Dal punto di vista urbano, l'azione più rilevante che ha riguardato il monastero e il suo immediato intorno è stata la variazione della sezione stradale adiacente al complesso, che da vico Incurabili è stato ampliato fino all'attuale configurazione. Le motivazioni che hanno portato alla demolizione del chiostro ancora non sono chiare, ma forse è stata attuata proprio in ragione dei flussi stradali che rendevano necessario un passaggio maggiore per accedere all'Ospedale degli Incurabili. La percezione del monastero dalla strada rimane caratterizzata da muri alti e irregolari che dichiarano l'introspettività dell'edificio; solo in corrispondenza dell'area del chiostro (che si trova a una quota di circa 4 metri di altezza rispetto alla strada carrabile) il muro di cinta si abbassa e lascia penetrare lo sguardo che dopo pochi metri incontra il limite del muro di tufo, ben visibile dall'esterno.

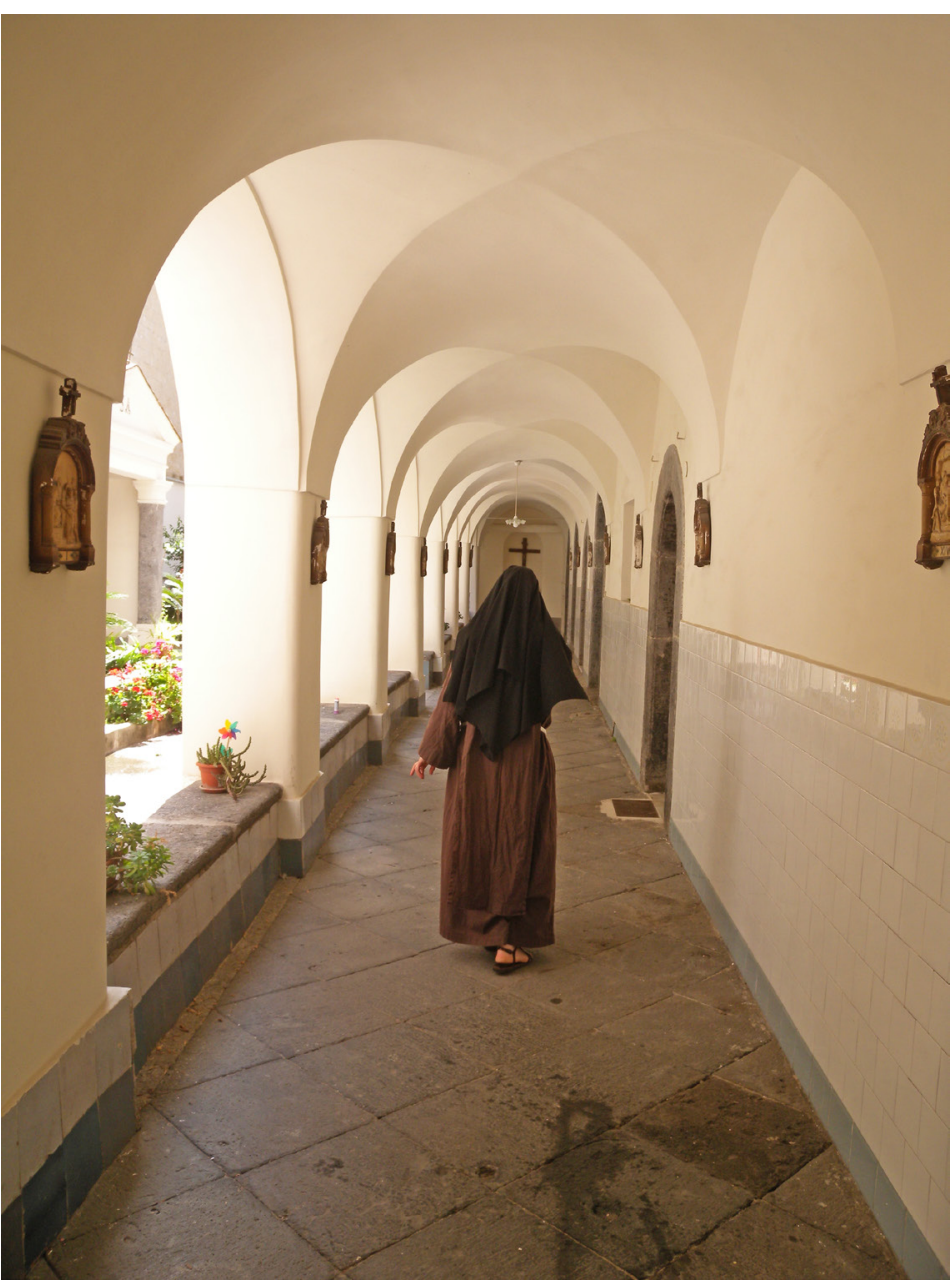




\section{Conclusioni}

Le riflessioni nate intorno al Monastero di Santa Maria in Gerusalemme si fondano sullo studio di questa struttura misconosciuta ma profondamente radicata nella cultura e nell'identità cittadina. Le vicissitudini storiche hanno profondamente messo alla prova il monastero, segnato da evidenti cicatrici, e la comunità religiosa che è oggi l'unica a Napoli ad avere una 'continuità di presenza' ovvero è la sola ad essere sopravvissuta alle leggi di soppressione, rimanendo sempre viva e in relazione con la gente del posto. Questa grande qualità umana insieme alla complessità architettonica della struttura rende il monastero delle Trentatré un interessante progetto di ricerca, soprattutto dal punto di vista della rappresentazione che ha il compito di riconsegnare le immagini perdute e proporre visioni per il futuro che utilizzando strategie visuali, più che costruttive, può restituire identità al luogo.

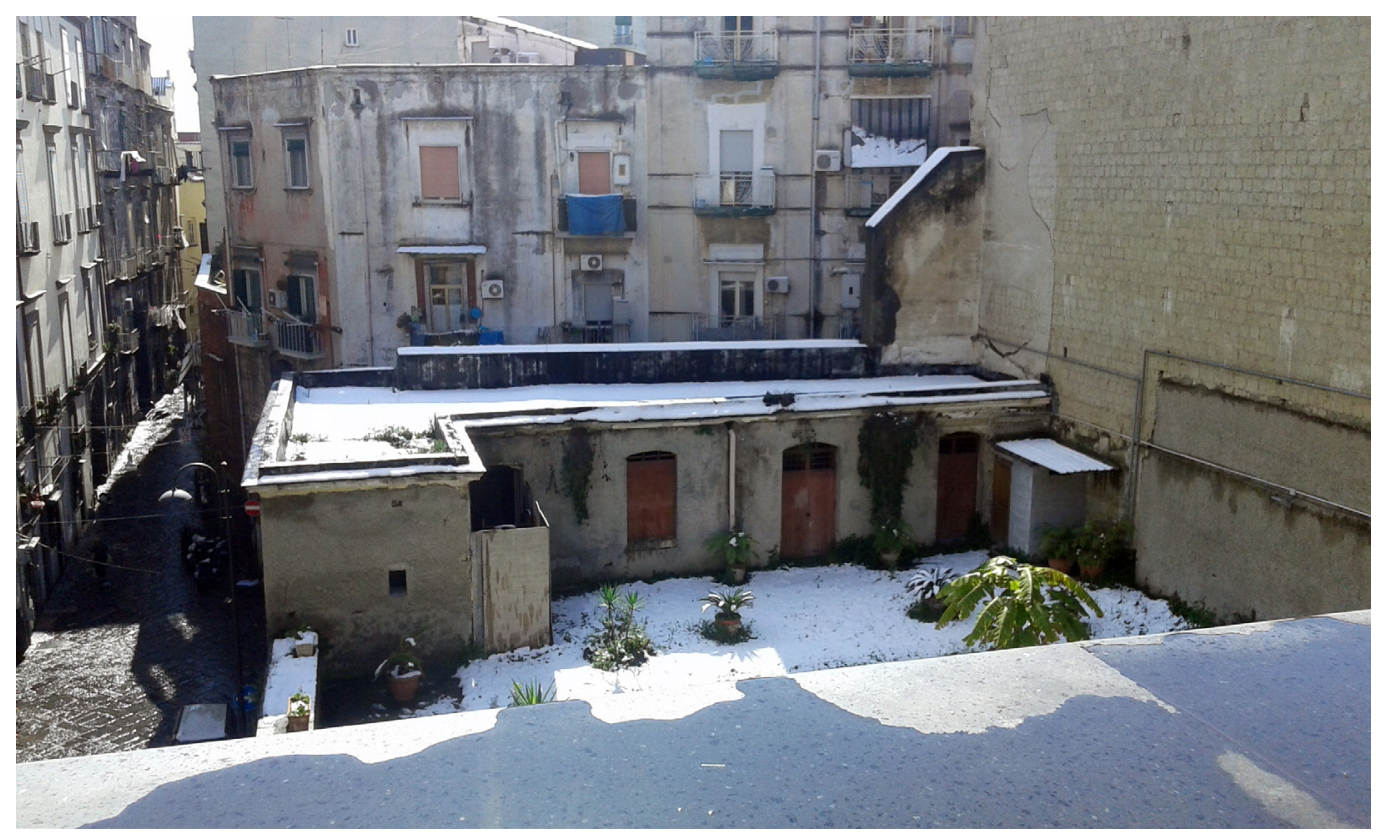

\section{Riferimenti bibliografici}

Archivio Clarisse Cappuccine, cart. IX, n. 4

Appiano Ave (1993). Comunicazione visiva. Apparenza, realtà, rappresentazione. Milano: UTET Libreria.

Buccaro Alfredo (2003). Napoli millenovecento. Dai catasti del XIX secolo ad oggi: la città, il suburbio, le presenze architettoniche. Napoli: Electa.

Margiotta Maria Luisa (200I). Il giardino sacro. Chiostri e giardini della Campania. Napoli: Elcta.

Ugo Vittorio (199I). I luoghi di Dedalo. Elementi teorici dell'architettura. Bari: Edizioni Dedalo.

\section{Autore}

Alice Palmieri, Università degli Studi della Campania 'Luigi Vanvitelli', alice.palmieri@unicampania.it

Per citare questo capitolo: Palmieri Alice (2020). Connessioni e narrazioni. Racconto di un monastero/Connections and narratives. Tale of a Monastery. In Arena A., Arena M., Brandolino R.G., Colistra D., Ginex G., Mediati D., Nucifora S., Raffa P. (a cura di). Connettere. Un disegno per annodare e tessere. Atti del $42^{\circ}$ Convegno Internazionale dei Docenti delle Discipline della Rappresentazione/Connecting. Drawing for weaving relationships. Proceedings of the 42th International Conference of Representation Disciplines Teachers. Milano: FrancoAngeli, pp. 3614-3633. 


\title{
Connections and Narratives. Tale of a Monastery
}

\author{
Alice Palmieri
}

Abstract

The interpretation of the term 'connect' reveals meanings that have different characteristics: in architecture, for example, the connection can be physical, given by the union of several spaces; it can be understood as a planning tool in the urban project of places; it can be relational, interpreting the connection as a communication. All the aspects highlighted, belong to the story of the Monastery of Santa Maria in Jerusalem, in the ancient centre of Naples: the theme of connection is a tool to understanding the dynamics of monastic life, the architectural transformations of the building and the urban variations in the immediate surroundings.

This paper proposes a research in itinere, born within the 'protocol of understanding' between the Department of Architecture and Industrial Design of the University of Campania 'Luigi Vanvitelli' and the Monastery of Santa Maria in Jerusalem, aimed to the historical reconstruction of the monastic structure and cloistered life, the relief and recovery of the Cloister, the project of enhancement and narrative. The work presented is based on archive research, visits and surveys carried out until now, which gradually give an increasingly complete picture of the architectural structure. In addition, because of the nature of the building, the perceptive aspects are meaningful, wide reflections could be done about the theme of multi-sensoriality and of reconstruction of lost images and views.

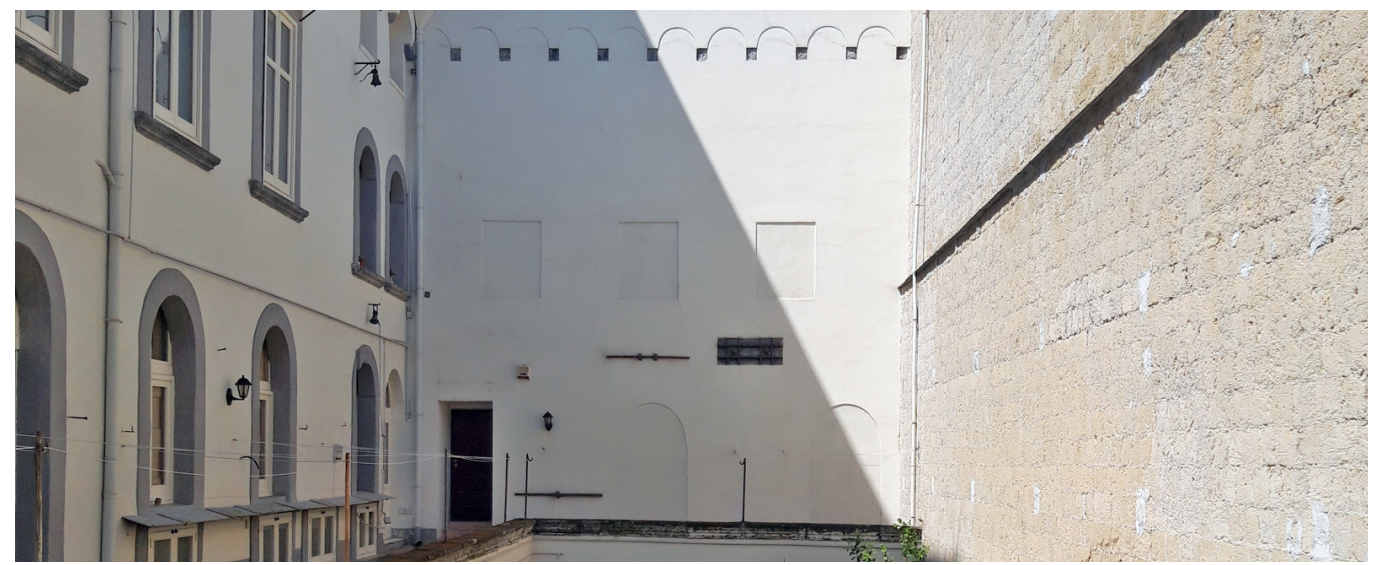




\section{Introduction}

To interpret the theme of connection implies the consideration of the multiple declinations of the verb 'to connect': to put together, to unite, to link, to relate. These are actions that can take on different meanings in the form and 'implementation' of the connection. The same semantics of the term manifest the interpretative possibilities that change respect to contextualization: in architecture it can mean a physical connection, made as a union of several environments in order to create a new spatial conformation or a relational connection, which reveals the communication and dialogue aspects, which may or may not correspond to a tangible continuity. Connecting can mean recalling to the memory, reuniting present and past, re-introducing into daily life the traces of an ancient history, perhaps distant in time, but imprinted in places. In this sense the memory becomes the starting point for the representation understood as the restitution of an image no longer present but perceptible. All the aspects highlighted belong to the story of the Monastery of Santa Maria in Jerusalem, in the ancient centre of Naples: a particular structure for its history and conformation, object of the 'Protocol of agreement' between the Department of Architecture and Industrial Design of the University of Campania 'Luigi Vanvitelli' and the Monastery in which the theme of connection is proposed as a key to understanding the dynamics of monastic life, the architectural transformations of the building and parallel to the urban variations of the immediate surroundings. The way to connect the two portions of the cloister that currently exist make it possible to imagine different approaches and arrangements to recompose spatial continuity. Story of the five centuries of history of this religious community and the visions for the future are articulated through the interpretation of the connection as the relationship between inside and outside, reintegration of the ancient cloister, connection with the city, visual strategies and accessibility.

Fig. I.Territorial view from the topographical Map of the Duke of Noja (1775) from which the configuration of the original cloister can be deduced.

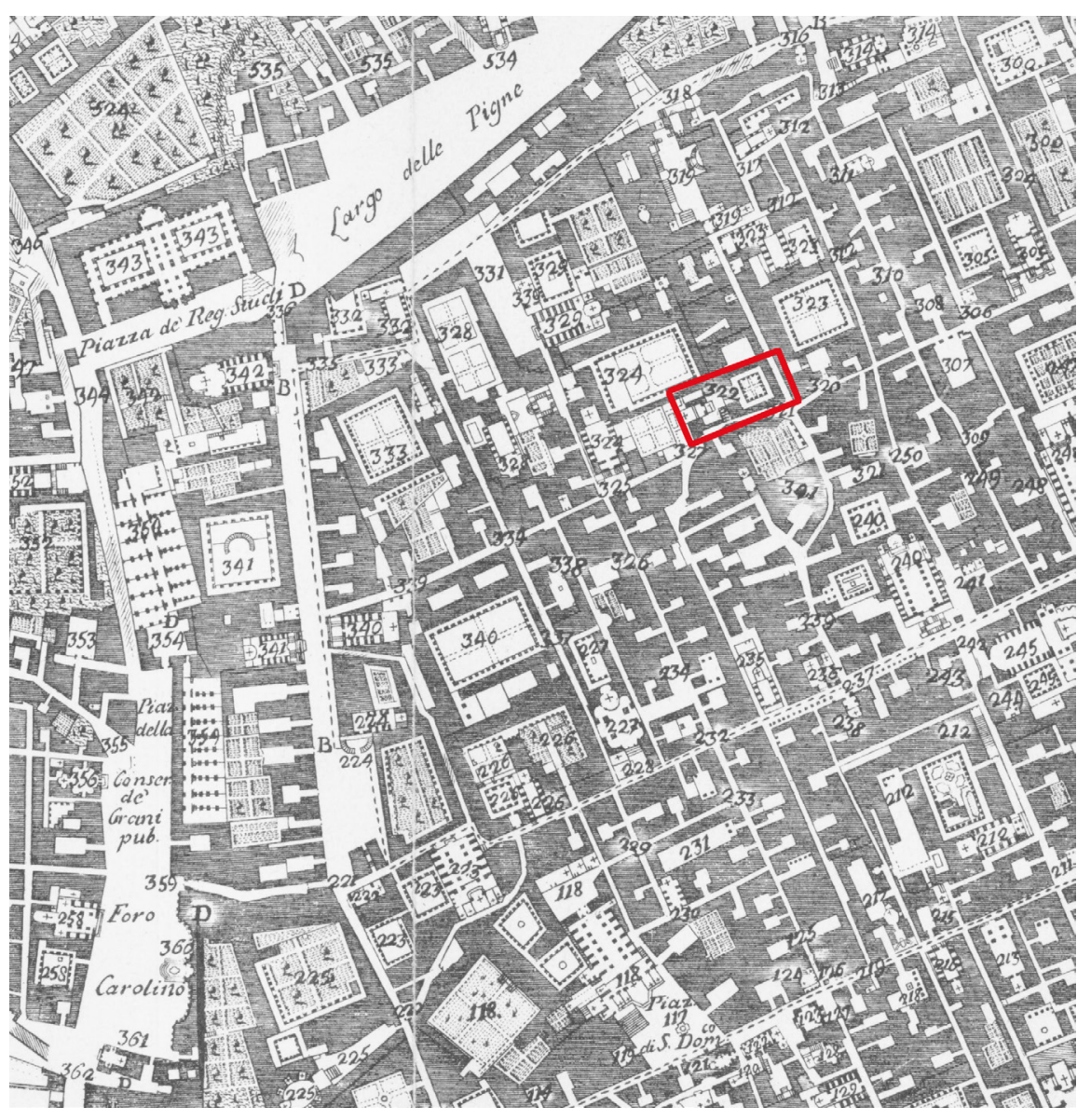




\section{History of the 'Thirty-three' Monastery}

The monastic complex of Santa Maria in Jerusalem, called 'Thirty-three' (from the number of nuns it could accommodate) was founded in the sixteenth century by the Catalan noblewoman Maria Lorenza Longo, who came to Naples in 1506 in the entourage of Ferdinand the Catholic. It is located in the Greco-Roman city, on the insula opposite the Odeon, not far from the ancient Neapolis theatre, within the ancient walls. The venerable Maria Lorenza Longo, after the foundation of the Incurabili Hospital (1519) received on February 19th, I 535 from Pope Paul III the edict Debitum Pastoralis officii with which she was authorized to welcome the nascent Capuchin community in the hospital. Due to the increased number of consecrated women, a transfer was necessary which became possible only in I585, when the nuns entered the present structure. The monastery respected the dictates of the typical architecture of Capuchin convents and overlooked two cloisters, an arcade and a simpler one that served as a vegetable garden. On the ground floor the complex was developed around the cloisters, where the workshops needed for the activities of the sisters (kitchen, pantries, laundry etc.) and the usual environments to allow the relational and emotional life of the nuns, making the cloister the real regulatory centre of common life. The upper floor was reserved for the dormitory with an entire wing for the infirmary, which was accessed from a parlour, with a chapel used for confession and visits by doctors. The coenoby is built with poor material, tuff and piperno, without pomp and with a good exposure to the sun, open and closed spaces alternating to allow the light necessary for cloistered life to enter the monastic insula. The entrance to the monastery is from via Pisaneli, through a wide staircase at the end of which there is access to the church and on the right are the wheel (still working today) and access to the space of the cloister.

With the post-unification suppression laws (|86|-|866) brutal transformations altered the monastic complex, demolishing and transforming considerable areas for the construction of rooms for 'the Incurabili' Hospital, to arrive in the twentieth century to the demolition of more than half of the cloister, the refectory and the upper floor with the entire dormitory.

Fig. 2. Part of the cloister still existing, interrupted by the construction of single front remains intact while the two side arms are incomplete.

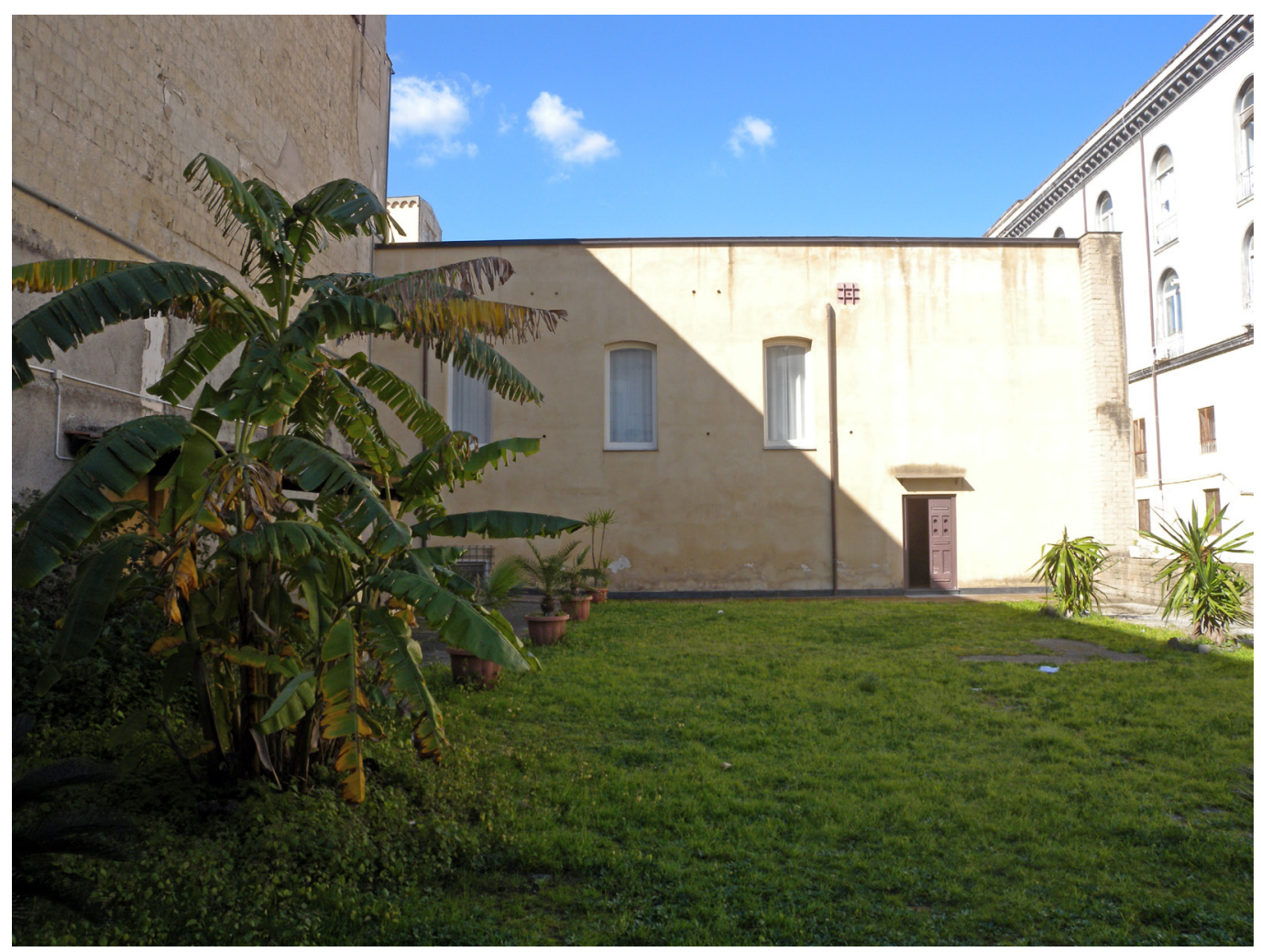


Fig. 4. Plan of the current state: the drawing shows the brutality of the intervention which, by demolishing the cloister, leaves the structure interrupted and without continuity.

Fig. 5. Longitudinal section A-A: the tuff wall, about 16 metres high, overlooks the reserved area for the cloister and the difference in height of the road that defines the level of the cloister is about 4 metres above road level.
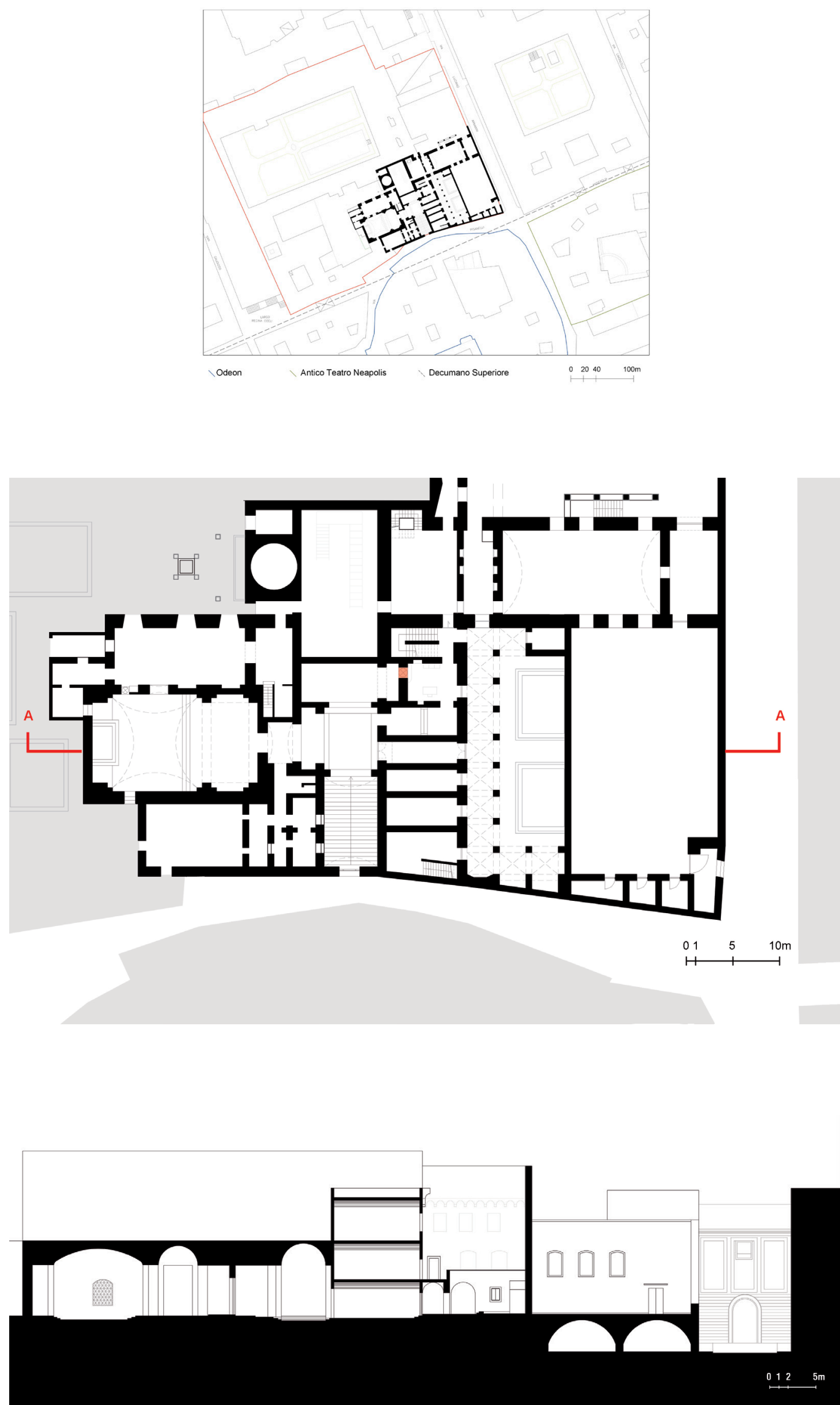
Fig. 6. The trace of the ancient facade draws on the wall the reconstruction of the ancient openings that tell the original distribution of the interiors.

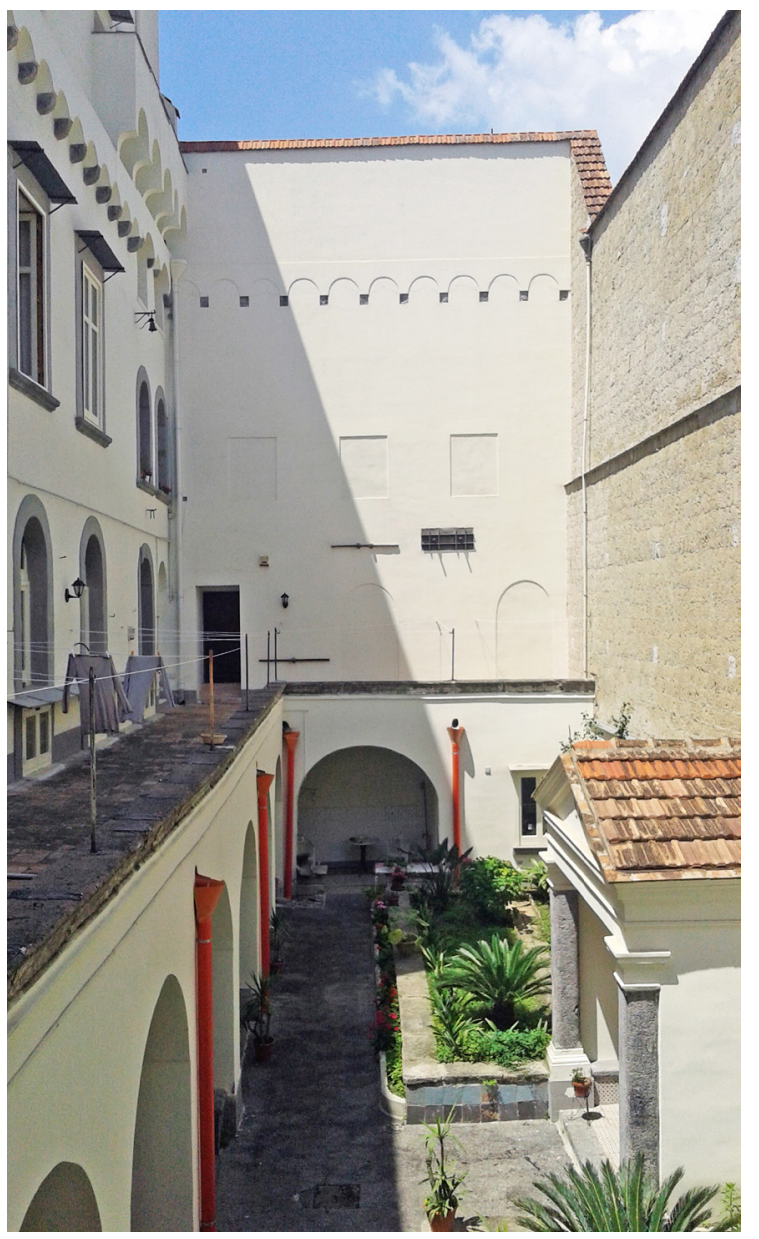

In concomitance of these events, vico degli Incurabili is widened becoming the current via Armanni and in the nuns' refectory, an anti-tubercular dispensary is set up. Later the area, reduced to a heap of ruins, is definitively abandoned after the earthquake of 1980. It was only in 2003 that the space of the former cloister was given on loan to the Monastery, which had hoped for its return, and in agreement with the Superintendence and the Campania Region, a project of philological reconstruction of the environments was realized. Renouncing the cloistering of these places, the fraternity has agreed to the construction of a multipurpose hall in the old refectory opened in 2009, now open to the public.

\section{Internal/external connection}

The prevailing characteristic in the perception of a cloistered monastery is inaccessibility. It has always represented in collective imagination a place where one cannot enter and above all, from which one cannot leave. The complicated and delicate choice of cloistered life is associated with the rule that prohibits the laic people from entering the internal parts of the convents and the obligation that some of the religious impose on themselves in the profession of vows, not to leave the monastery. For this reason the term 'cloistered' is also understood as 'closure', implying the denial of any connection with the world and external life. Approaching the reality of the Capuchin Poor Clares who live in the Monastery of Santa Maria in Jerusalem, a different story emerges instead from what we can imagine. In full respect of the rule, many citizens enter into a deep connection with the nuns and their home, through the wheel. The definition of 'wheel' corresponds to the architectural element, 
Fig. 7. The Monastery seen from Via Armanni: the high irregular walls enclose the cloistered area, except for the space occupied by the former cloister, partially visible from the street.

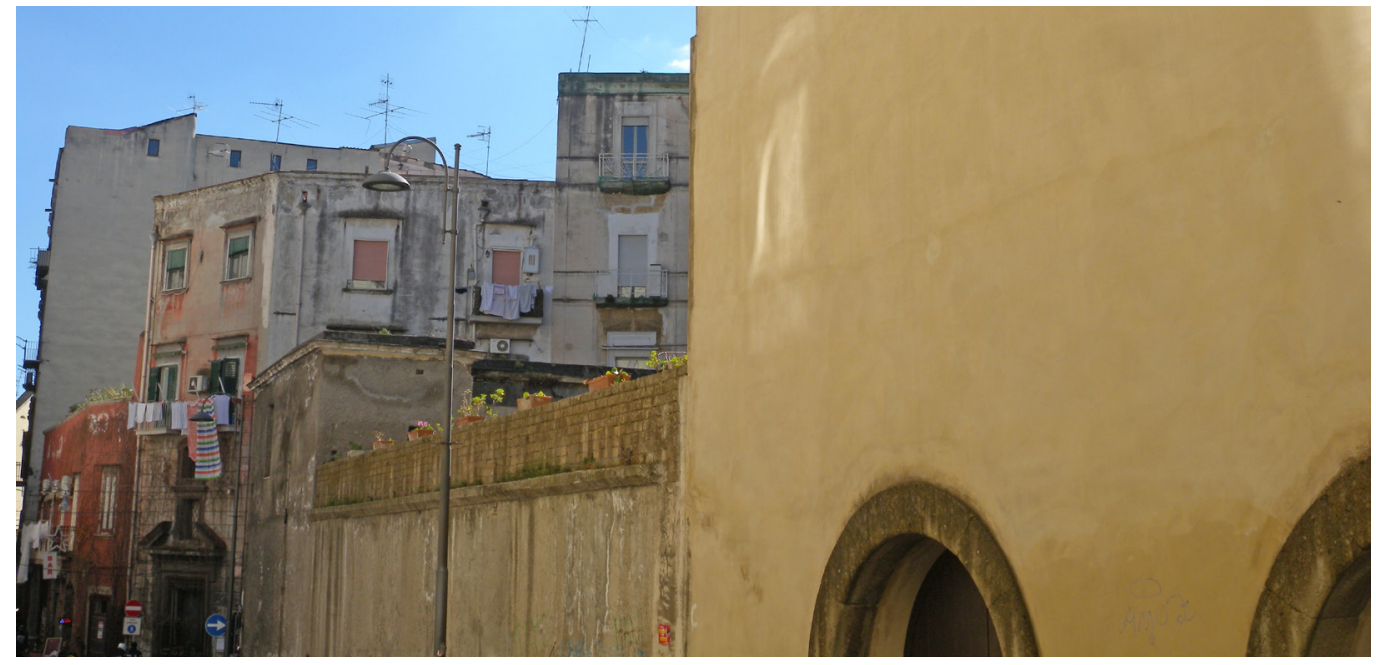

usually wooden, consisting of a rotating mechanism of cylindrical shape and divided into two closed parts: one towards the inside and another towards the outside which, matching an opening on a wall, allows an exchange with the nuns without any visual contact. In the monastery of the 'Thirty-three', the wheel never welcomed infants, so it was not a "wheel of the exposed", but was used to donate the "providences" with which the nuns were supported and, as is still the case today, it is the place of listening where the Poor Clares welcome the local people who entrust them with prayers, intentions and confidences. The wheel is the element that allows the relationship with the outside, it is the point where stories, tales, smells, sounds, voices... a small gap, which with the rotation brings things from one side to the other, from outside to the inside, from the secular world to the sacredness and privacy of the monastery. A multisensory experience in which sight, today's dominant

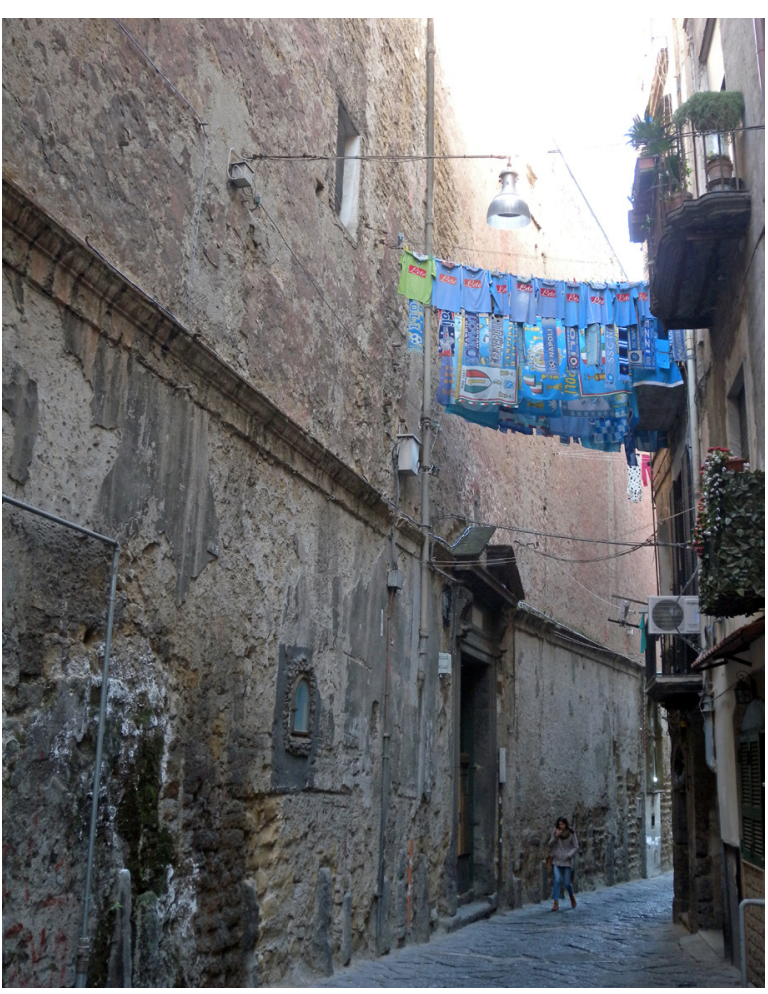


sense, is denied. In fact, when we talk about connection, it is always taken for granted that the conjunction of several places also implies visual continuity, while the wheel denies this condition and proves to be an instrument of an unprecedented circumstance, which interplays all the other senses - mainly hearing- making the participants in the relationship inside/outside active and operational components of the connection. A heavy filter like the wheel could seem an obstacle to communication, an insurmountable limit (perhaps), instead somehow the connection is amplified, stripped of the superfluous and reduced to the essential it overcomes the obstacle.

In the text Visual Communication, Ave Appiano describes the sensory manifestations as "those rich elaborations carried out by the mind, so as to activate a communication between reality and the mind; the information received by the brain through the senses is configured in the way dictated by thought and becomes images. [...] The image is therefore not only representation, figure or effect of given realities, but the result of a mental activity and therefore must be considered as the result of that communicative process that takes place between the individual and reality" [Appiano 1993, p. 4]. This consideration, which deeply analyses communication as a connection between a person and the surrounding environment, in the case of the wheel leads to a very significant conclusion that, although the visitor has no visual contact with the world beyond the object, he is able to deduce an image of it, based on an alternative perception, which, using hearing, smell and proxemics, enters into a relationship with an invisible reality.

Fig. 9. The space of the demolished cloister now is an unlivable garden fo the religious commuprospect of the adjacent refectory.

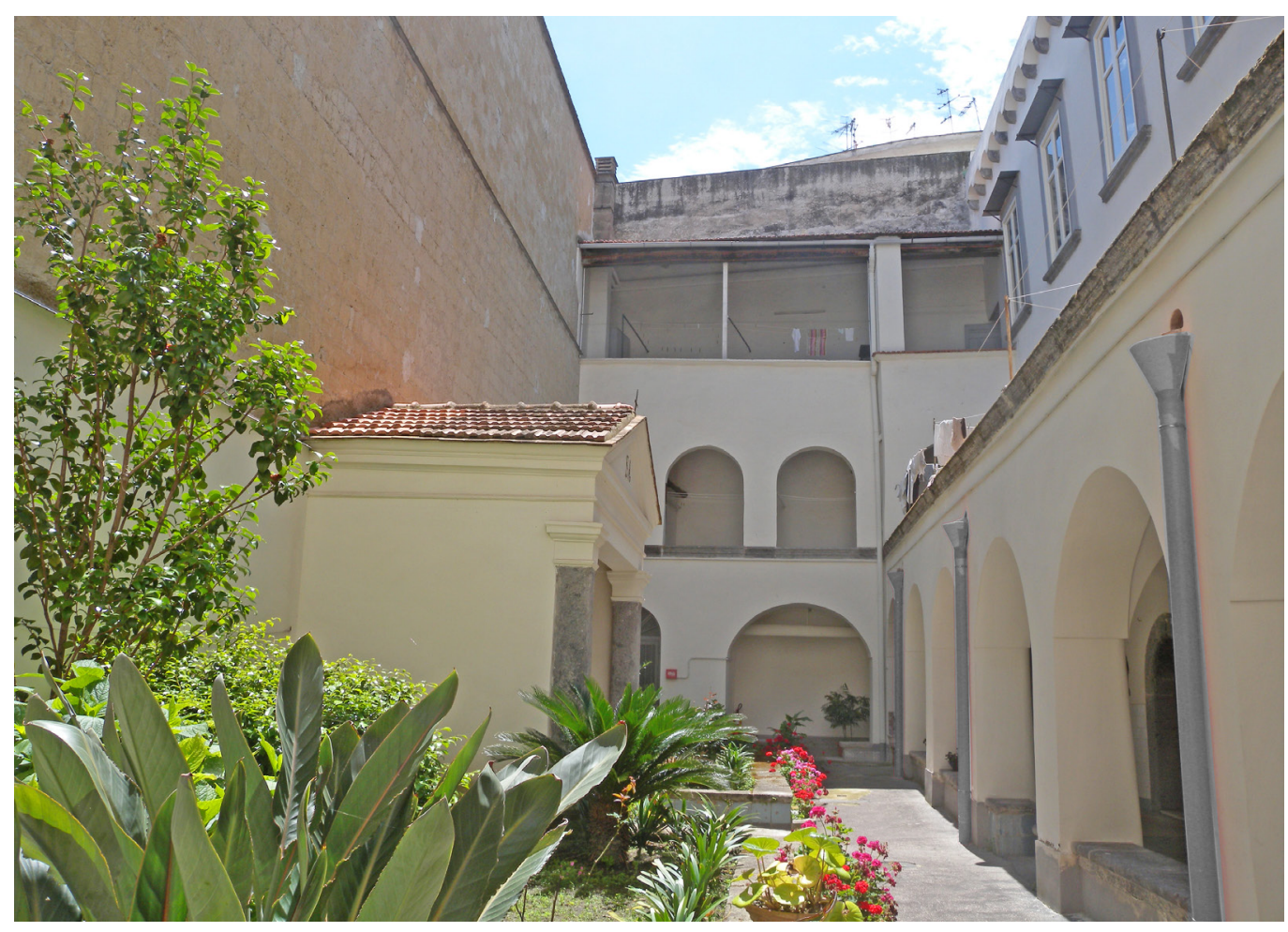

\section{Connecting to the past}

What we might call a 'blank' in the image of the inner world of the monastery can therefore be overcome by a perceptive experience that assigns to visitors the responsibility of constructing an idea autonomously based on multisensory knowledge and the ability to conceive and imagine the cloistered dimension. The Monastery of Santa Maria in Jerusalem, as anticipated in the description of the history of the complex, has a further blank that is 
now the subject of study and research. The question of the demolition of the cloister, in fact, is still unresolved, although funds have been allocated for the demolition of the wall that divides the two parts. All the space that was originally occupied by the cloister is now divided into a small band in which there is an entire front of the ancient arcade, and a larger area on the side of Via Luciano Armanni that is not usable by the nuns because it does not respect the conditions of confidentiality provided by the rule. Although small, the portion of the cloister that still exists constitutes a precious trace for the understanding of the architectural articulation modified during the twentieth century. First of all, the intact portico reveals the probable configuration of the other sides, supported by a plan drawn up in I864, following the decree of suppression of the houses of religious orders. This archive documentation contains the ground floor plan to which are attached descriptions of the distribution of the rooms on the upper levels and then the cells that followed the perimeter of the cloister on the second floor. In addition to this, in recent times, on a blind facade overlooking the existing cloister, traces of the ancient windows and the final frame of the facade have been brought to light. The returned image appears as a full-scale drawing, a representation that alludes to the voids that no longer exist and that is proposed as a perpetual narration of the state of the places. The redevelopment of the facade has restored consistency to the space that is no longer limited by a blind wall, but is surrounded by the symbolic representation of the place it has been, a sign of memory and narration of a lost reality that still aspires to be told.

The presence/absence of the cloister and the original facades is the central theme in the architecture of the monastery because the desire to live the complete (and complex) experience of the place where the design, in the broad sense of representation and 'assignment of meaning', can be a valuable tool of intervention.

"In absence of the original design, one's experience can take place both - and this is the most frequent case - in its representations, understood as configurations and techniques (drawing, painting, photography, cinema, description, ...) capable of rendering somehow visually present what is not materially present, both in the remembrance of a past experience, and finally through the mediation of the imaginative activity that, in the case of the architect, takes the form of the project" [Ugo 1991, p. 58].

The experience that Vittorio Ugo defines as 'mediated' is therefore made possible by representation, memory and project-imaging. This kind of approach certainly includes the redevelopment of the facade, while the possible implementations to render the memory of the cloister intact, which would be unlikely to be reconstructed, but using new technologies and storytelling strategies, can still be the subject of narrative.

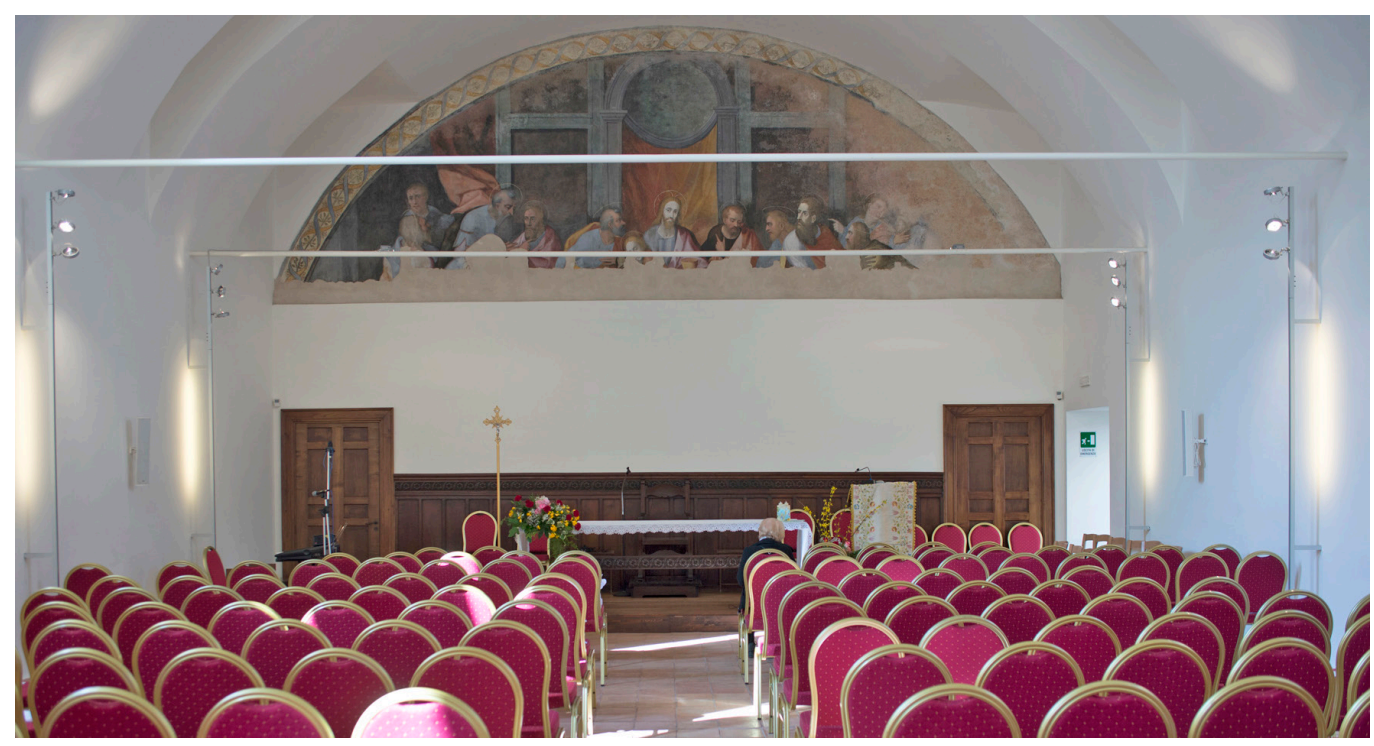




\section{Relationship with the city}

With the restoration work carried out over the last twenty years, the community of Capuchin Poor Clares has accepted the opening to the public of some areas of the monastery. In particular, the refectory, completely rebuilt, is now used for concerts, conferences, meetings with the nuns and charity sales. This space overlooks the area of the former cloister, delimited by the high tuffaceous wall and also accessible, as well as the cellars from which you enter directly from the street and which could become in the near future a museum of ceramics. The inhabitants entering the monastery are facilitated in the perception and promotion of knowledge and with it all the issues related to the demolition of the cloister to which many show great sensitivity.

From the urban point of view, the most relevant action that concerned the monastery and its immediate surroundings was the variation of the road section adjacent to the complex, which from vico Incurabili has been extended to the current configuration. The reasons that led to the demolition of the cloister are still unclear, but perhaps demolition was implemented due to the road flows that needed a greater passage to access the Hospital of the Incurables. The perception of the monastery from the road remains characterized by high and irregular walls that declare the introspectivity of the building; only in correspondence with the cloister area (which is about 4 meters high compared to the driveway) the boundary wall becomes lower and allows the eye to penetrate up to a few meters where it meets the limit of the tuff wall, clearly visible from the outside.

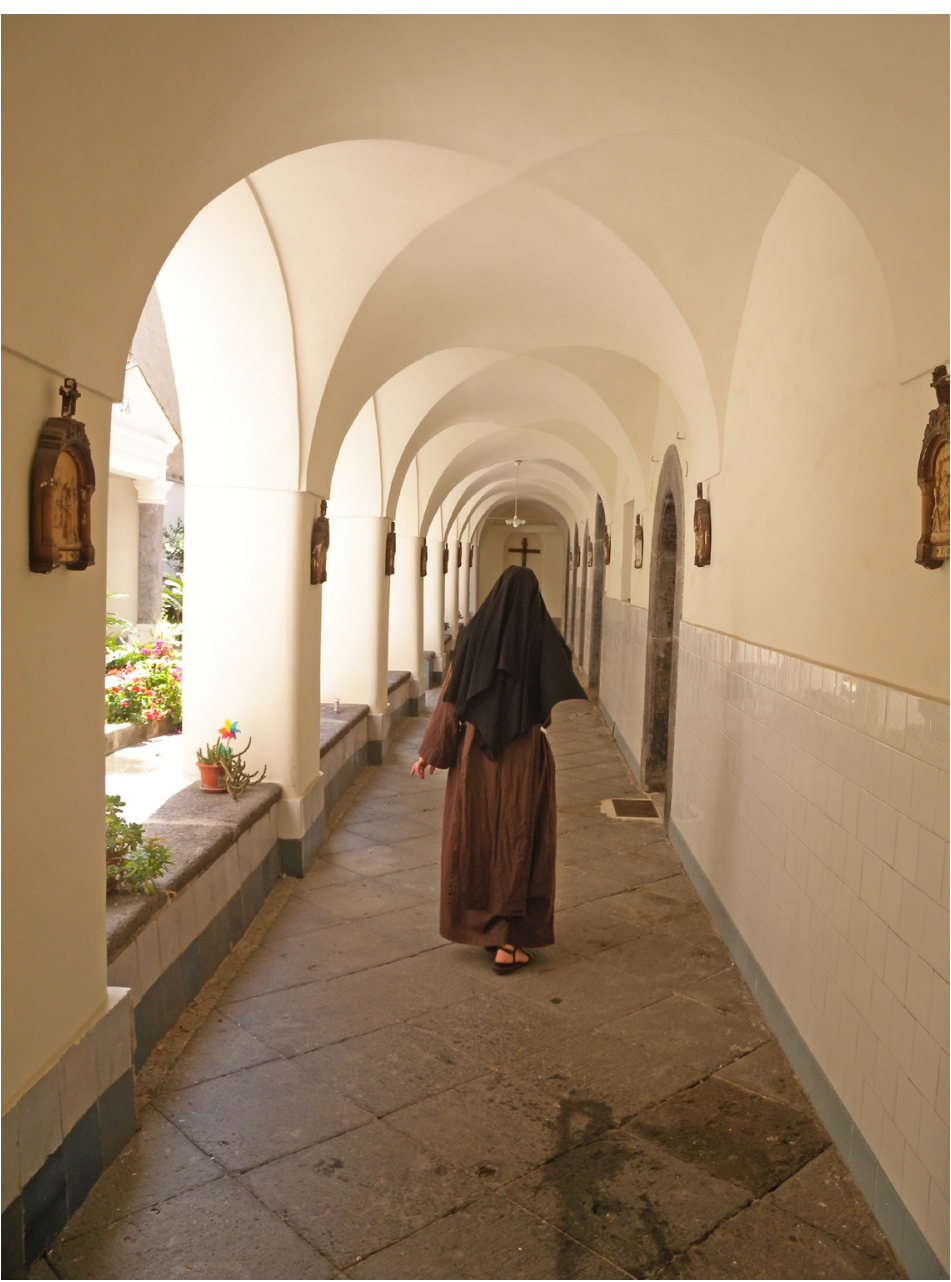




\section{Conclusions}

The reflections born around the Monastery of Santa Maria in Jerusalem are based on the study of this unrecognized structure but deeply rooted in the culture and identity of the city. The historical vicissitudes have profoundly challenged the monastery, which bears obvious scars, and the community itself, which today is the only one in Naples to have a "continuity of presence", that is, it is the only one to have survived the laws of suppression, always remaining alive and in relation to the locals. This great human quality together with the architectural complexity of the structure makes the Thirty-three monastery an interesting research project, especially from the point of view of representation, which has the task of returning lost images and proposing visions for the future that using visual rather than constructive strategies, can give back identity to the place.

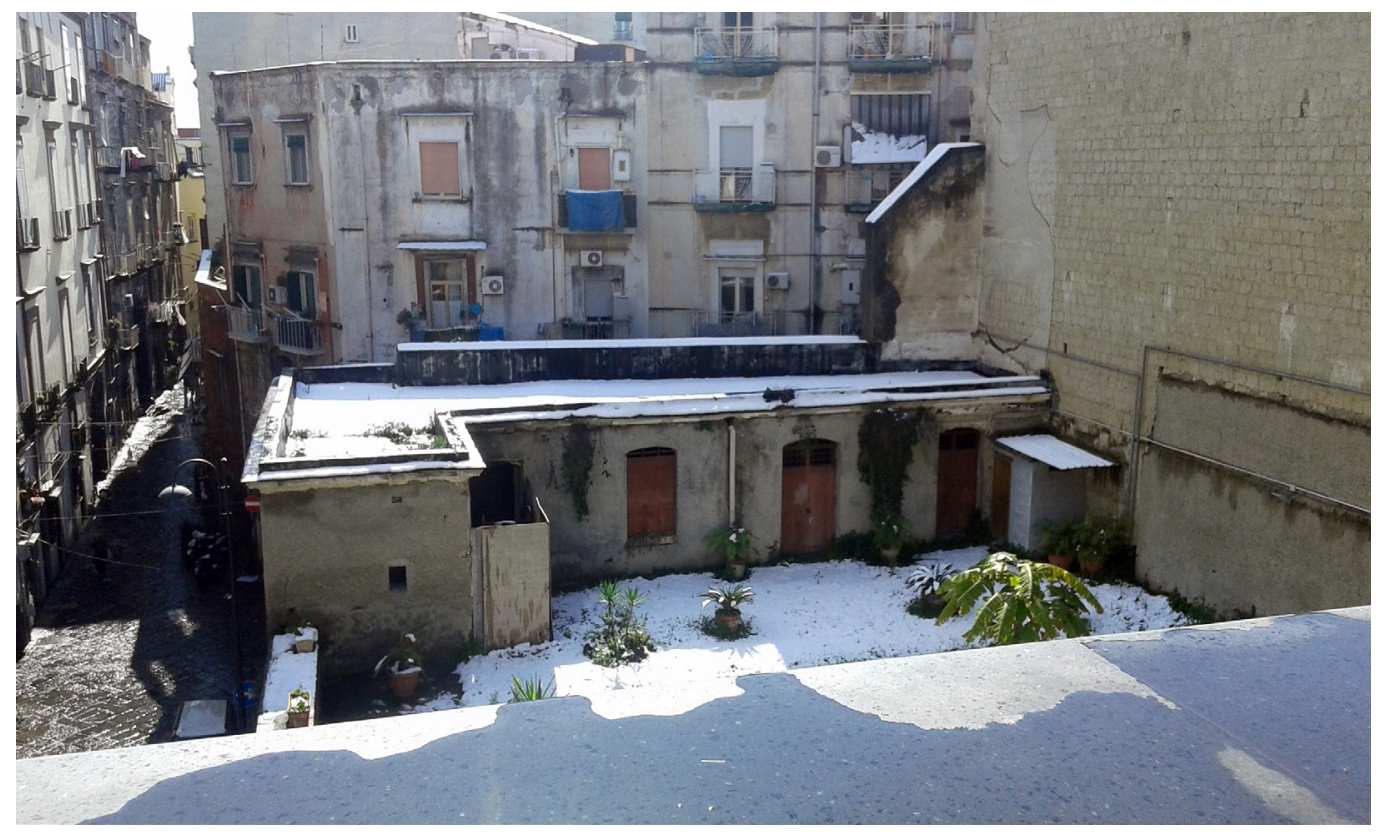

\section{References}

Archivio Clarisse Cappuccine, cart. IX, n. 4.

Appiano Ave (1993). Comunicazione visiva. Apparenza, realtà, rappresentazione. Milano: UTET Libreria.

Buccaro Alfredo (2003). Napoli millenovecento. Dai catasti del XIX secolo ad oggi: la città, il suburbio, le presenze architettoniche. Napoli: Electa.

Margiotta Maria Luisa (200 I). Il giardino sacro. Chiostri e giardini della Campania. Napoli: Elcta.

Ugo Vittorio (|99|). I luoghi di Dedalo. Elementi teorici dell'architettura. Bari: Edizioni Dedalo.

\section{Author}

Alice Palmieri, Università degli Studi della Campania 'Luigi Vanvitelli', alice.palmieri@unicampania.it

To cite this chapter. Palmieri Alice (2020). Connessioni e narrazioni. Racconto di un monastero/Connections and narratives. Tale of a Monastery. In Arena A., Arena M., Brandolino R. G., Colistra D., Ginex G., Mediati D., Nucifora S., Raffa P. (a cura di). Connettere. Un disegno per annodare e tessere. Atti del $42^{\circ}$ Convegno Internazionale dei Docenti delle Discipline della Rappresentazione/Connecting. Drawing for weaving relationships. Proceedings of the 42th International Conference of Representation Disciplines Teachers. Milano: FrancoAngeli, pp. 36|4-3633. 